\title{
Comparative Evaluation of the Lighted Intubation Stylet, Storz DCI Videolaryngoscope, and Macintosh Laryngoscope in Adult Patients
}

\author{
Erișkin Hastalarda Ișıkı Entübasyon Stilesi, Storz DCI Videolaringoskop ve Macintosh Laringoskopun \\ Karșılaștırılması
}

\author{
Hatice Bahadır, Hediye Ayla Tür, Cengiz Kaya, Ersin Köksal, Yasemin Burcu Üstün, Elif Bengi Șener, Ahmet Dilek \\ Department of Anesthesiology, School of Medicine, Ondokuz Mayzs University, Samsun, Turkey
}

\begin{abstract}
AIM: To compare a lighted intubation stylet (LIS), Storz DCI videolaryngoscope, and Macintosh laryngoscope regarding endotracheal intubation (ETI) times, the number of intubation attempts required, hemodynamic findings, and complications related to intubation-extubation.
\end{abstract}

METHODS: A total of 60 patients age 18-65 with American Society of Anesthesiologists score I-II and Mallampati score I-II, who were scheduled for elective surgery, were randomized into 3 groups: Group I, on which ETI was performed using the LIS; Group V, on which ETI was performed using the Storz DCI videolaryngoscope; and Group L, on which ETI was performed using the Macintosh laryngoscope. For each study group, ETI was applied by an operator who had previously performed at least 15 successful endotracheal intubations. Heart rates (HRs), mean arterial pressure (MAP), and peripheral oxygen saturation (SpO2) were recorded before and after induction, immediately, and 1, 2, 3, 4, and 5 minutes after ETI. However, ETCO2 was recorded immediately, and 1, 2, 3, 4, and 5 minutes after ETI. In addition, the number of attempts required to achieve ETI, ETI-related complications, and ETI times were noted. Potential complications were recorded immediately, and also 2 and 6 hours after extubation.

RESULTS: The demographic characteristics of the patients, ETI times, HR, MAP, ETCO2, and SpO2 did not differ between groups. Immediately after extubation, complications (stridor, coughing) were seen in 2 (10\%) patients in Group L; however, they weren't observed in other groups $(p=0.362)$. Sore throat was seen in Groups I $(n=2 ; 10 \%), V(n=1 ; 5)$ and $L(n=2 ; 10 \%)(p=0.804)$. Two hours after extubation, sore throat was observed in one (5\%) patient in both Group I and $L(p=0.596)$.

CONCLUSION: There wasn't difference between the LIS, Storz$D C l$ videolaryngoscope and Macintosh laryngoscope with respect to hemodynamic parameters, the number of ETI trials, ETI times, and related complications.

Key words: lighted intubation stylet; Storz DCl videolaryngoscope; Macintosh laryngoscope; intubation

Yard. Doc. Dr. Cengiz Kaya, Ondokuz Mayıs Üniversitesi Anestezi ve Rean. AD. Kurupelit,Samsun-Türkiye, Tel.05056793359Email.raufemre@yahoo.com Geliş Tarihi: 25.08.2014 • Kabul Tarihi: 08.02.2015

\section{ÖZET}

AMAÇ: Erișkin hastalarda, lighted intubation stylet, Storz DCI videolaringoskop ve Machintosh laringoskop arasında endotrakeal entübasyon (ETI) süresi, entübasyon için girișim sayısı, entübasyon-ekstübasyon ilișkili komplikasyonlar, hemodinamik bulguların karșılaștırılması.

YÖNTEM: Çalıșmaya, yașları 18-65 arasında değișen, American Society of Anesthesiologists skoru I-II, Mallampati skoru I-II, elektif cerrahi uygulanacak 60 hasta dahil edildi. Hastalar rastgele üç gruba ayrıldı; Grup I: LIS ile ETI, Grup V: Storz DCI video laringoskop ile ETI, Grup L: Machintosh laringoskop ile ETI yapılan grup. ETI her çalıșma grubu için en az 15 bașarılı deneme yapan uygulayıcı tarafından yapıldı. Grupların kalp atım hızı (KAH), ortalama arter basıncı (OAB), periferik oksijen satürasyonu (SpO2), indüksiyondan önce, indüksiyondan sonra, ETl'dan hemen sonra, ETI'dan sonraki 1., 2., 3., 4. ve 5. dakikalarda kaydedildi. ETCO2 ise ETI'dan hemen sonra, ETI'dan sonraki 1., 2., 3., 4. ve 5. dakikalarda kaydedildi. Ayrıca ETI'nin kaçıncı denemede gerçekleștiği, ETI esnasında olușan komplikasyonlar ve ETI süresi de tespit edildi. Ekstübasyon sonrası komplikasyonlar ise ekstübasyondan hemen sonra, 2. saatte ve 6 . saatte kaydedildi.

BULGULAR: Gruplar arasında demografik özellikler, ETI süreleri, $K A H, O A B, E T C O 2$ ve SpO2 açısından farklıık saptanmamıștır. Ekstübasyon sonrası komplikasyonlara bakıldığında ise ekstübasyondan hemen sonraki komplikasyonlar (stridor, öksürük) Grup L'de iki (\%10) hastada görülürken diğer gruplarda görülmedi ( $p=0.362)$. Boğaz ağrısı ise Grup l'da 2 (\%10), Grup V'de 1 (\%5), Grup L'de $2(\% 10)$ hastada görüldü $(p=0.804)$. Ekstübasyon sonrası 2. saatte boğaz ağrısı komplikasyonu Grup I ve L'de birer (\%5) hastada görüldü ( $p=0.596)$.

SONUÇ: Çalıșmamızda, LIS, Storz-DCI Videolaringoskop ve Machintosh laringoskop karșılaștırıldığında hemodinamik parametreler, ETI deneme sayısı, ETI süresi ve komplikasyonlar açısından fark yoktu.

Anahtar kelimeler: ıșıklı entübasyon stilesi; Storz DCl videolaringoskop; Macintosh laringoskop; entübasyon 


\section{Introduction}

Endotracheal intubation (ETI) is the placement of a tube within the trachea in order to secure the respiratory tract and/or control respiration ${ }^{1}$. ETI was first performed by Curry in 1792 using a tactile method ${ }^{1}$. Later on, in 1895 , Kirstein used a laryngoscope to achieve ETI, while in 1920, Magill used ETI with the intent to institute anesthesia ${ }^{1}$.

ETI is routinely performed under general anesthesia, preferably following muscular relaxation. Under direct laryngoscopic visualization of the glottis, an endotracheal tube is inserted into the oral cavity and engaged in the trachea ${ }^{1,2}$. The development of digital technology has enabled the fabrication of video laryngoscopes for better visualization of the glottis ${ }^{3}$. Video laryngoscopes combine a standard laryngoscope blade with an endoscopic system ${ }^{4}$. In this system, the camera is mounted on an ergonomically designed laryngoscope handle to obtain a larger (king-size) view of the airway structures ${ }^{4}$.

A lighted intubation stylet (LIS) is a long, flexible instrument with a battery in its handle and a light source mounted on its tip ${ }^{5,6}$. When LIS is placed within the trachea, a pretracheal glow can be easily seen, whereas when the laryngoscope is slipped into the esophagus, the pretracheal glow cannot be seen. Because of this advantageous characteristic of LIS, this stylet has been included in this algorithm for the management of difficult airways, as formulated by the American Society of Anesthesiologists (ASA) ${ }^{7}$. During insertion of the LIS, manipulation of the head and neck is rarely required, and a large mouth opening is not a must ${ }^{8}$.

During ETI, stimulation of the laryngeal and tracheal tissues induces reflexive increases in sympathoadrenal activity, leading to the emergence of physiopathological changes such as tachycardia, and increases in blood, intracranial, and intraorbital pressure ${ }^{1,9}$. In healthy individuals, these reactive responses are generally well tolerated, while in patients with limited coronary or myocardial reserves, they can lead to myocardial ischemia or failure?.

In our study, we aimed to compare the effects of these technological devices on the duration of ETI performed using a standard laryngoscope, the number of failed ETI attempts, hemodynamic responses, complications that might develop following intubation, and extubation procedures.

\section{Material and Methods}

In our double-blind, randomized, positive-controlled study, we compared the advantages and disadvantages of the LIS, Storz DCI videolaryngoscope, and Macintosh laryngoscope in patients who would undergo ETI procedures (Figure 1). Our study was performed in the Department of Anesthesiology and Reanimation after the approval of the Ethics Committee of Ondokuz Mayıs University, Faculty of Medicine was obtained in compliance with the directives of the Declaration of Helsinki.

A total of 60 patients age 18-65 with American Society of Anesthesiologists score (ASA) I-II and Mallampati score I-II who were scheduled for elective surgery were included in the study. Patients with a higher ASA risk (>II) and Mallampati (>II) scores, pregnant women, hypertensives, $\beta$-blocker users, obese (body mass index $\geq 30 \mathrm{~kg} / \mathrm{m}^{2}$ ) individuals, patients with complaints, and symptoms of coughing, stridor, foreign substance,
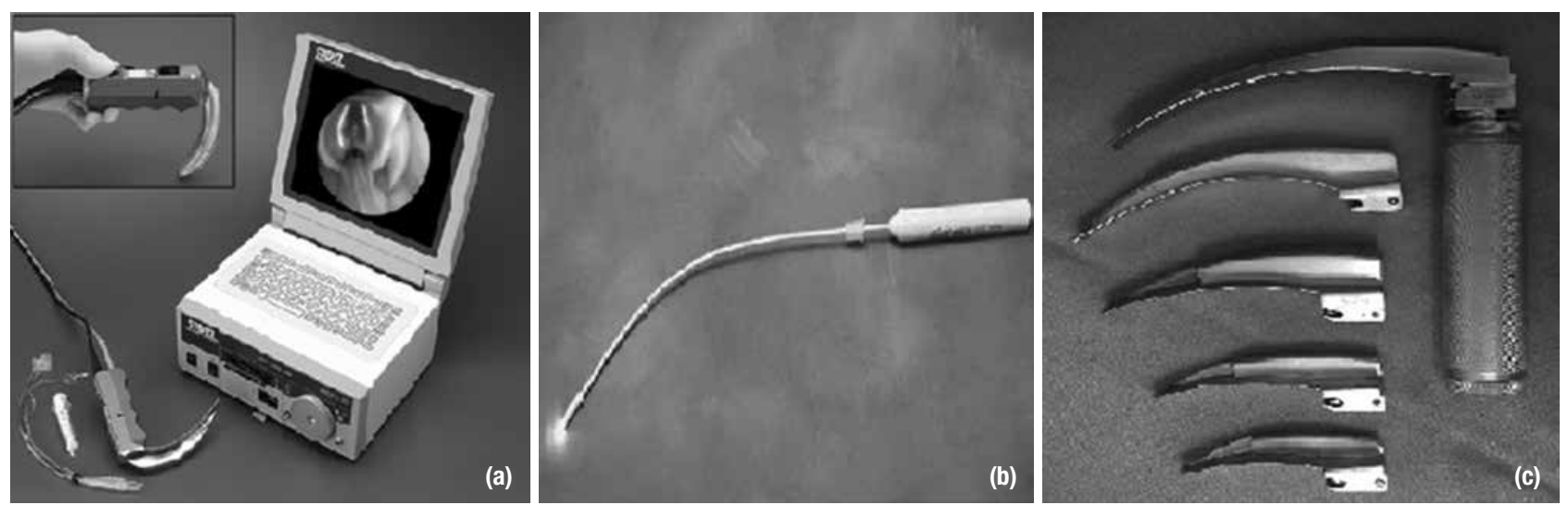

Figure 1. a-c. Storz DCI Video Laryngoscope ${ }^{19}$ (a); Lighted Intubation Stylet20 (b); Macintosh Laryngoscope ${ }^{21}$ (c) 
tumour, polyp, and abscess in the upper respiratory tract were excluded from the study. Besides, patients for whom three ETI attempts failed were excluded from the study.

Signed informed consent forms were obtained from all study participants and then the patients were randomized into 3 groups based on random number tables. Each group consisted of 20 patients as follows:

Group I: ETI was performed using the LIS;

Group V: ETI was performed using the Storz DCI video laryngoscope;

Group L: ETI was performed using the Macintosh laryngoscope.

After positioning the patient on the operating table, monitorizations of the patients were performed based on electrocardiographic (ECG) examination results, noninvasive blood pressure, and peripheral oxygen saturation $\left(\mathrm{SpO}_{2}\right)$ measurements. For the induction of anesthesia, $2.5 \mathrm{mg} / \mathrm{kg}$ propofol IV, $0.5 \mathrm{mg} / \mathrm{kg}$ aritmal, and $1 \mu \mathrm{g} / \mathrm{kg}$ fentanyl were administered through an intravenous route. Muscle relaxation was achieved with IV $0.6 \mathrm{mg} / \mathrm{kg}$ rocuronium. All ETIs were performed by operators who had used the LIS, Storz DCI video laryngoscope, and Macintosh laryngoscope at least 15 times.

In Group I, all lights in the operating room were turned off and the mouth of the patient lying in a neutral position was opened. Then the patient's lower jaw was held and lifted up with the anesthetist's non-dominant (usually left) hand. With his/her dominant hand, the anesthetist held the LIS already placed in the tube and slid it over the midline of the tongue until the pretracheal glow was seen at the level of the cricothyroid cartilage. Then the stylet was withdrawn delicately with simultaneous insertion of the tube in to the trachea.

In Group V, the Storz DCI video laryngoscope was held with the non-dominant hand and the patient's mouth was opened slightly. The patient's tongue was deviated to the left and a laryngoscope blade was inserted at the midline towards the oropharynx, then the tip of the blade was engaged in the vallecula. An endotracheal tube with its stylet was inserted from the right side of the mouth and its tip was advanced through the vocal cords, and the stylet was withdrawn.

In Group L, the Macintosh laryngoscope was held with the non-dominant hand of the anesthetist and the patient's mouth was slightly opened with his/her dominant hand. The tongue was placed to the left side of the blade and the tip of the blade was advanced towards the oropharynx, and engaged in the vallecula. When the rima glottis was visualized, an endotracheal tube was inserted from the right side of the mouth and advanced between the vocal cords.

In all groups, when auscultation of the lungs revealed equivalent pulmonary ventilation, the cuff of the endotracheal tube was inflated until the air-leak sound ceased. The position of the endotracheal tube was confirmed by an end-tidal carbon dioxide $\left(\mathrm{ETCO}_{2}\right)$ monitor, then the patient was connected to the ventilation system.

The heart rate (HR), mean arterial pressure (MAP), and $\mathrm{SpO}_{2}$ of the patients were recorded before and after the induction of anesthesia, immediately, and 1,2,3,4, and 5 minutes after ETI. However, $\mathrm{ETCO}_{2}$ was recorded immediately, and 1,2,3,4, and 5 minutes after ETI. Besides the number of interventions attempted to achieve ETI, complications occurred during the ETI procedure (bleeding, laceration, etc.) and procedural times were determined. Post-extubation complications (coughing, stridor, hoarseness, sore throat, and laryngospasm, etc.) were recorded immediately, and 2 and 6 hours after extubation.

The time that elapsed from opening the mouth to placing the endotracheal tube in the oral cavity up to the detection of the $\mathrm{ETCO}_{2}$ was termed ETI time in Group I. However, in the other groups, the time from the placement of the laryngoscope blade into the oral cavity up to the detection of the $\mathrm{ETCO}_{2}$ value was considered the procedural time. A 20\% increase from baseline systolic arterial pressure was recorded and intervened with IV perlinganit at a dose of $1 \mu \mathrm{cg} / \mathrm{kg}$.

\section{Statistical Analyses}

Data were analyzed using the statistical package for social sciences (SPSS) V.15. Assuming a statistical power of $80 \%$ and an alpha of 5\%, 20 patients in each group were required to reach a statistical significance. The compatibilty of continuous data with normal distribution was evaluated using the Shapiro-Wilk test. Since $\mathrm{SpO}_{2}$ values did not fit to the normal distribution curve, but medians, and other continuous variables demonstrated normal distribution, they were expressed as means \pm standard deviation. For intergroup comparisons of continuous data which displayed normal distribution One-Way Analysis of Variance (ANOVA) and 
Tukey HSD tests; for those incompatible with normal distribution Kruskal- Wallis Analysis of Variance were used. For pairwise comparisons of distinctly different parameters, the Mann-Whitney $U$ test was employed. For intergroup comparisons of quantitative data, a multi-level $c h i$-square test was used. $P<0.05$ was considered to signify a level of significance.

\section{Results}

No statistically significant intergroup difference was found for demographic characteristics, anesthesia, operative and ETI times, $\mathrm{HR}, \mathrm{MAP}, \mathrm{ETCO}_{2}$, and $\mathrm{SpO}_{2}$ ( $>>0.05)$ (Table 1 and 2) (Figure 2).

In all three groups, patients were intubated on the first attempt and no complications were observed following the ETI procedures.

As far as immediate post-extubation complications are concerned, stridor and coughing were only seen in 2 (10\%) patients in Group L $(\mathrm{p}=0.362)$. Sore throat was observed in Groups I $(n=2 ; 10 \%)$ and V $(n=1$;
$5 \%)(\mathrm{p}=0.804)$. Sore throat was also seen at the 2-hour mark following extubation (one patient in Groups I and $L$, respectively) $(\mathrm{p}=0.596)$.

\section{Discussion}

The achievement and maintenance of airway patency are among the essential responsibilities of an anesthesiologist ${ }^{10}$. A delay in the achievement of airway patency may cause hypoxia and subsequently anoxia, irreversible brain damage, or even death ${ }^{10}$. The perpetuation of vital functions depends on the achievement and maintenance of airway patency ${ }^{10}$. Therefore, making necessary preparations, taking required measurements, and ensuring the maintenance of the airway evaluation and the achievement of its patency are among the responsibilities of an anesthesiologist ${ }^{10}$.

In failed cases of ETI, other alternatives to standard ETI have been applied. Among them, ETI procedures performed using a Storz DCI Video Laryngoscope and LIS can be enumerated ${ }^{10}$.

Table 1. Demographic distribution of the groups (mean \pm standard deviation; $n, \%$ )

\begin{tabular}{lccc}
\hline & Group I $(\mathrm{n}=20)$ & Group V $(\mathrm{n}=20)$ & Group L $(\mathrm{n}=20)$ \\
\hline Gender & $10(50 \%)$ & $10(50 \%)$ & $10(50 \%)$ \\
Female & $10(50 \%)$ & $10(50 \%)$ & $10(50 \%)$ \\
Male & & & $12(60 \%)$ \\
*ASA & $16(80 \%)$ & $14(70 \%)$ & $8(40 \%)$ \\
I & $4(20 \%)$ & $6(30 \%)$ & 0.500 \\
II & $42.35 \pm 14.98$ & $41.65 \pm 14.45$ & $42.40 \pm 11.84$ \\
Age (years) & & & 0.386 \\
Mallampati Score & $10(50 \%)$ & $11(55 \%)$ & $8(60 \%)$ \\
I & $10(50 \%)$ & $9(45 \%)$ & $8(40 \%)$ \\
II & & & 0.982 \\
\hline ASA: American Society of Anesthesiologists. & & & \\
\hline
\end{tabular}

Table 2. Anesthesia, ETI, and operative times in all groups (mean \pm standard deviation)

\begin{tabular}{lccc}
\hline & Group I $(\mathrm{n}=20)$ & Group V $(\mathrm{n}=20)$ & Group L $(\mathrm{n}=20)$ \\
\hline Anesthesia time $(\mathrm{min})$ & $119.75 \pm 39.35$ & $107.75 \pm 46.46$ & $115.25 \pm 41.62$ \\
"ETI time & $17.25 \pm 5.32$ & $20.30 \pm 3.79$ & $19.65 \pm 4.34$ \\
$(\mathrm{sec})$ & & & 0.669 \\
Operative time (min) & $105.00 \pm 38.14$ & $94.50 \pm 39.89$ & $97.25 \pm 38.84$ \\
\hline ETI: Endotracheal Intubation. & & & 0.090 \\
\hline
\end{tabular}




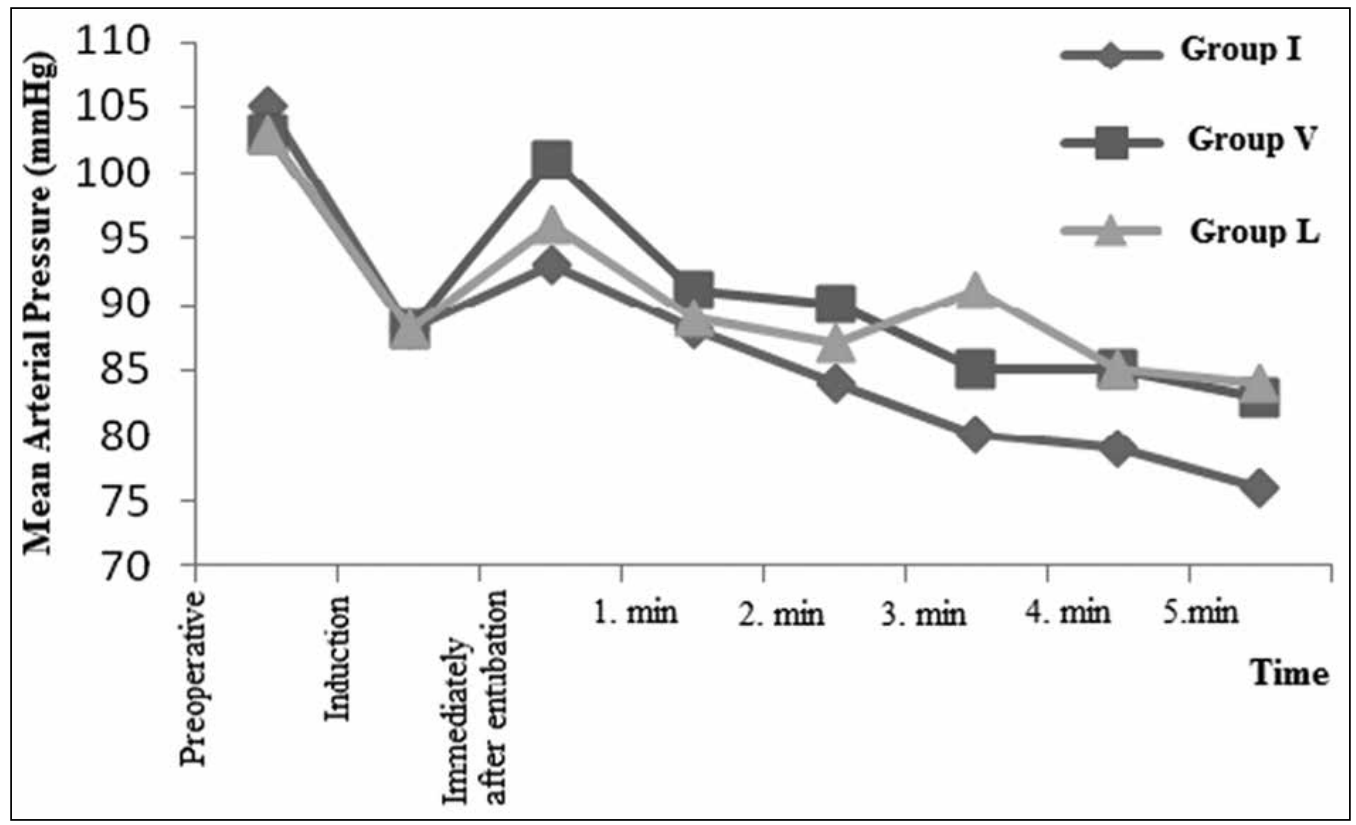

Figure 2. Mean arterial pressure measurements of the groups.

In their study, Sui et al. compared the Bonfils fiberscope and the LIS (Trachlight-TM), and detected shorter operative times for ETI procedures performed with the LIS ${ }^{11}$. However, Cavus et al. compared operative times for ETI performed using the C-MAC Video Laryngoscope or Macintosh laryngoscope ${ }^{12}$. Despite relatively longer operative times for ETI performed with the C-MAC Video Laryngoscope, they recommended the potential use of the C-MAC Video Laryngoscope as a standard ETI method for both management of airway patency and training purposes ${ }^{12}$. However, Healy et al. compared the use of a GlideScope, C-MAC, Storz-DCI Video Laryngoscopes, and Macintosh laryngoscope in a simulation mannequin, and obtained improved glottis visualization with the GlideScope, C-MAC, and Storz-DCI Video Laryngoscopes compared with the Macintosh laryngoscopes ${ }^{13}$. However, they observed longer ETI times with the GlideScope and Storz-DCI Video Laryngoscopes, relative to the Macintosh and C-MAC video laryngoscopes ${ }^{13}$. However, in our study, ETI times were similar in all groups. We think that these controversial outcomes cited in the literature might be associated with differences in the amount of experience the operators had with these laryngoscopes.

Park et al. compared the Airtraq video laryngoscope and LIS in the routine management of the respiratory airway and, as is seen in our study, no intergroup difference was found regarding ETI attempts, procedural time, and hemodynamic responses ${ }^{14}$. Turkstra et al. evaluated and compared the required mobility of cervical vertebra for the LIS, GlideScope Video Laryngoscope, and Macintosh laryngoscopy ${ }^{15}$. In conclusion, they observed minimal mobility of cervical vertebra during LIS when compared with other laryngoscopic procedures. This phenomenon may explain the lesser impact of ETI performed with the LIS on hemodynamic responses.

Montes et al. analyzed the effects of LIS and Macintosh laryngoscopy on hemodynamic response rates in patients with coronary artery disease and, as in our case, they couldn't find any difference between the two procedures (Montes et al., 2003). Still, similar to our study, in patients who had undergone LIS, somewhat lower hemodynamic values were detected. In other studies, also similar to our study, LIS affected hemodynamic values to a lesser extent than Macintosh laryngoscopy without any statistically significant difference between these procedures ${ }^{16-18}$.

Friedman et al. compared the use of the LIS and Macintosh laryngoscopes, and detected relatively fewer complication rates with the use of the LIS $^{18}$. Sue et al. compared the Bonfils fiberscope and LIS, and noted relatively lower complication rates with the use of the LIS ${ }^{11}$. Kihara et al. evaluated the Macintosh 
laryngoscope, LIS, and Fastrach LMA for their relevant complication rates, and revealed higher complication rates with the use of Fastrach LMA, while they couldn't detect any difference in complication rates between the Macintosh laryngoscopy and LIS ${ }^{17}$. However, in our study, no difference was found between groups regarding complication rates.

In conclusion, in our study, no statistically significant difference was found among the LIS, Storz-DCI Video Laryngoscope, and Macintosh laryngoscope with respect to hemodynamic parametres, the number of ETI attempts, ETI procedural time, and related complications.

\section{References}

1. Kayhan Z. Endotrakeal Entübasyon. In: Kayhan Z, ed. Klinik Anestezi. Vol 13 ed. İstanbul: Logos 2004:243-73.

2. Henderson J. Airway management in the adult. In: Miller RD, ed. Miller's Anesthesia Vol 26 ed. United States: Churchill Livingstone; 2005:1617-52.

3. Channa AB. Video laryngoscopes. Saudi Journal of Anaesthesia. Oct 2011;5(4):357-9.

4. Kaplan MB, Ward DS, Berci G. A new video laryngoscope-an aid to intubation and teaching. Journal of Clinical Anesthesia. Dec 2002;14(8):620-6.

5. Kaya K GR, Öztürk E. Entübasyonda güçlük ve laringoskop gerektirmeyen teknikler (Intubation difficulty and techniques that do not require laryngoscope). Anestezi Dergisi 1996;4:57-68.

6. Bhimsan N. Equipment in the SMART Centre. 2014. [cited 11 August 2014]. Available from:http://smart.ukzn.ac.za/ equipment.aspx.

7. Practice guidelines for management of the difficult airway: an updated report by the American Society of Anesthesiologists Task Force on Management of the Difficult Airway. Anesthesiology. May 2003;98(5):1269-77.

8. Favaro R, Tordiglione P, Di Lascio F, et al. Effective nasotracheal intubation using a modified transillumination technique. Canadian journal of anaesthesia = Journal Canadien D'anesthesie. Jan 2002;49(1):91-5.

9. Mallick A, Klein H, Moss E. Prevention of cardiovascular response to tracheal intubation. British Journal of Anaesthesia. Aug 1996;77(2):296-7.
10. Toker K. Zor havayolu. In: Keçik Y, ed. Temel Anestezi. Ankara: Güneş Tıp Kitabevi; 2012:907-15.

11. Sui JH, Mao P, Liu JH, et al. Transillumination-assisted orotracheal intubation: a comparison of the Bonfils fibrescope and the lightwand (Trachlight). Acta Anaesthesiologica Scandinavica. May 2012;56(5):565-70.

12. Cavus E, Thee C, Moeller T, et al. A randomised, controlled crossover comparison of the C-MAC videolaryngoscope with direct laryngoscopy in 150 patients during routine induction of anaesthesia. BMC Anesthesiology 2011;11:6.

13. Healy DW, Picton P, Morris M, et al. Comparison of the glidescope, CMAC, storz DCI with the Macintosh laryngoscope during simulated difficult laryngoscopy: a manikin study. BMC Anesthesiology 2012;12:11.

14. Park EY, Kim JY, Lee JS. Tracheal intubation using the Airtraq: a comparison with the lightwand. Anaesthesia. Jul 2010;65(7):729-32.

15. Turkstra TP, Craen RA, Pelz DM, et al. Cervical spine motion: a fluoroscopic comparison during intubation with lighted stylet, GlideScope, and Macintosh laryngoscope. Anesthesia and Analgesia. Sep 2005;101(3):910-915, table of contents.

16. Jain A, Naithani M. Infant with unanticipated difficult airway - Trachlight to the rescue. Journal of Anaesthesiology, Clinical Pharmacology. Jul 2012;28(3):361-3.

17. Kihara S, Brimacombe J, Yaguchi Y, et al. Hemodynamic responses among three tracheal intubation devices in normotensive and hypertensive patients. Anesthesia and analgesia. Mar 2003;96(3):890-5, table of contents.

18. Friedman PG, Rosenberg MK, Lebenbom-Mansour M. A comparison of light wand and suspension laryngoscopic intubation techniques in outpatients. Anesthesia and Analgesia. Sep 1997;85(3):578-82.

19. Endoskope KS. DCI ${ }^{\circ}$ Video Laryngoscope System. 2014. [cited 11 August 2014]. Available from: https://www.karlstorz.com/ cps/rde/xchg/SID-0EDAFA15-D0F78905/karlstorz-en/ hs.xsl/9590.htm.

20. Publishing T-C. Intubating Airway Management (Clinical Essentials) (Paramedic Care) Part 4. 2014. [cited 11 August 2014]. Available from: http://what-when-how.com/paramediccare/intubating-airway-management-clinical-essentialsparamedic-care-part- $4 /$.

21. Wikipedia. Laryngoscopy. 2014. [cited 11 August 2014]. Available from: http://en.wikipedia.org/wiki/Laryngoscopy. 